\title{
IPO Pricing Phenomena: Empirical Evidence Of Behavioral Biases
}

\author{
Michael Adams, Jacksonville University \\ Barry Thornton, Jacksonville University \\ George Hall, Jacksonville University
}

\begin{abstract}
Does IPO stand for Instant Profit Opportunity or It's Probably Over-priced? The conundrum is that both answers are generally correct. The answer appears to depend on the investor's investment horizon. This realization provides an enigma for the Efficient Market Hypothesis (EMH) proponents. It is widely known that initial public offering (IPO) stocks in the past have typically been underpriced, thereby allowing the fortunate purchaser to buy the shares in the primary market and systematically beat the stock market averages. This phenomenon is evidenced by the average one-day returns on IPOs of $15 \%$ and presents a puzzle to efficient market advocates. Behavioral finance posits that the same underpriced IPO stocks will under-perform the market and deliver substandard performance during the ensuing one to three years. At a minimum, the "new-issues puzzle" presents a challenge to the EMH and has given rise to many class-action stockholder lawsuits alleging illegal price manipulation. Why under-pricing systematically happens and why issuing firms/major shareholders choose to leave copious amounts of money on the table is not well explained by traditional financial theory. Behavioral finance melds together investor psychology and normative financial theory in an attempt to explain this market enigma.
\end{abstract}

¿ $\mathrm{s}$ an initial public offering (IPO) a virtual money machine enabling informed investors to systematically beat the stock market? The offering prices of new firms going public are regularly under priced $10-15 \%$ and those investors who participate in the offering have a free lunch on the issuing firm's checkbook. It is well documented that IPOs substantially underperform market indexes both in the short and long term. For academic researchers, this paradox raises questions concerning market efficiency. For investors, it raises questions concerning the benefits of ever investing in a new issue, except in the initial offering. For companies, it raises the question as to why they allow so much money to remain on the table. There appear to be several explanations, both rational and irrational, as to why investors hold IPOs long term and why companies allow their initial stock to be underpriced. Depending on the investment horizon and whether the investor can acquire the IPO shares at the initial offer price, flipping the IPO on the first day of trading amounts to a "free lunch on Wall Street."

A well known and documented phenomenon is the first day return typically generated by IPOs. This is also known as the initial under pricing practice of investment bankers. The initial under pricing of the IPO is the difference between the price obtained by the shares at the close of the first trading day and the price of the offer, adjusting for the market return in that same period. The average under pricing for all IPOs in 2006 was $11.57 \%$ and the initial adjusted return was $10.93 \%$. This under pricing is a direct cost to the issuing company. Furthermore, the owners of the firm prior to the IPO suffer a higher dilution of their ownership. If IPO markets are efficient as defined by EMH, issuers should generally receive market value for the shares issued, and investors should not regularly be able to purchase IPOs at a discount to their market value. The following three research questions will be addressed: (1) Why are IPOs systematically underpriced? (2) Does the EMH apply to the IPO market? (3) Why do companies allow so much wealth to be transferred to informed investors?

There is clear and unambiguous evidence that investment bankers systematically under price IPOs. There is a history of significant jumps in the price of IPOs on the first day of trading. The average $7.4 \%$ gain in the 1980s exploded to $65 \%$ in 1999, capped by the $698 \%$ first-day gain for VA Software Corporation. With investors frantic for hot issues, anyone who could get shares at the opening price generally cleaned up. As a result, some investment 
bankers exacted kickbacks and other quid pro quos from clients who were allocated shares in the offering. Credit Suisse First Boston allegedly handed out shares to customers who would kick back some of the gains through inflated commissions. Without admitting or denying the charges, the firm paid a \$100 million SEC penalty.

The losers in this game were the issuing companies and investors who held the IPO after the first-day of trading. At the height of the dot.com boom, these new companies could have reaped an average of $\$ 79$ million more in capital had their offering prices been closer to what the market would pay. Some investors benefited from the "friends and family" system. However, insiders can't benefit from the under pricing, since they typically can't sell their own shares for 180 days (standard lock-up provision). These insiders are often more concerned with maintaining good relations with the investment bankers whose analysts are trying to create buzz about their company. According to University of Florida finance Professor Jay R. Ritter, "Managers have many incentives to ignore the money they've left on the table."

These "new issue" anomalies appear to be exceptions to the EMH, which defines the degree of market efficiency pricing in terms of the amount of relevant information available (Fama 1976). Bossaerts (2004) states that the rationality implied in the EMH is too strict for the IPO market due to the limited information about IPO firms in the aftermarket. The ongoing debate is whether the anomaly in IPO initial under pricing and long term under performance (Ritter 2004) is a manifestation of market inefficiency caused by the irrational behaviors of investors and IPO issuing firms. Many theories, none of which are mutually exclusive, have been advanced to explain under pricing. The correlation between initial under-pricing and the factors associated with this behavior is not straightforward. Moreover, the reasoning investors use to hold IPOs long-term is unclear.

The issuing company (or major stockholders) will lose money if an IPO is significantly underpriced. The loss (money left on the table) is determined as the number of shares in the offering multiplied by the difference between the first day opening price and the offer price. In 2006, this loss was estimated to be $\$ 4.8$ billion. The average under-pricing for the latest period (April 2007 - June 2007) is 11\%, which is less than the period from 1980 to 2001. This is considerably less than the dotcom years of 1999 and 2000 (Table 1).

Table 1

\begin{tabular}{|c|c|c|c|c|c|c|c|c|}
\hline \multicolumn{9}{|c|}{ IPO Summary } \\
\hline & 1999 & 2000 & $\underline{2001}$ & 2002 & 2003 & $\underline{2004}$ & 2005 & $\underline{2006}$ \\
\hline Number of Deals & $\overline{486}$ & $\overline{406}$ & $\overline{83}$ & $\overline{70}$ & $\overline{68}$ & $\overline{216}$ & $\overline{194}$ & $\overline{198}$ \\
\hline Total Proceeds (Billions) & $\$ 93$ & $\$ 97$ & $\$ 41$ & $\$ 24$ & $\$ 15$ & $\$ 43$ & $\$ 34$ & $\$ 43$ \\
\hline Average Deal Size (MM) & $\$ 291$ & $\$ 240$ & $\$ 491$ & $\$ 338$ & $\$ 224$ & $\$ 198$ & $\$ 175$ & $\$ 217$ \\
\hline Total Return & $276 \%$ & $-18 \%$ & $16 \%$ & $3 \%$ & $28 \%$ & $34 \%$ & $18 \%$ & $26 \%$ \\
\hline Aftermarket Return & $111 \%$ & $-38 \%$ & $2 \%$ & $-5 \%$ & $14 \%$ & $21 \%$ & $6 \%$ & $13 \%$ \\
\hline $1^{\text {st }}$ Day Return & $72 \%$ & $56 \%$ & $14 \%$ & $9 \%$ & $12 \%$ & $12 \%$ & $12 \%$ & $12 \%$ \\
\hline
\end{tabular}

Even though the current IPO under-pricing is considerably less than previous years, it still constitutes \$27.6 million of money left on the table for the $2^{\text {nd }}$ quarter of 2007. Over the past 15 years, the share price of the typical IPO closed roughly 15 percent above the offer price on the first day of trading. These high initial returns are captured by the original share purchasers rather than by the issuing company. Why IPOs are consistently underpriced is a mystery. Presumably, the firm's management and original shareholders would prefer to receive a higher price for their shares. Traditional economic theory is predicated upon the concept of wealth maximization as the driving force behind a firm's economic decision-making and cannot fully explain this systematic under pricing.

Behavioral finance theory offers several possible explanations for the under-pricing phenomenon. Several theoretical models have been developed, and each has gained some empirical support. Perhaps the most obvious reason that underwriters choose to systematically under-price new stock is to make it easier for them to market the issue. This intentional under-pricing will reduce the chances that the issue will be undersubscribed, resulting in capital loss to the underwriters. If the offering is undersubscribed, the underwriter may be forced to take a "haircut" 
on his inventory of shares. Aversion to loss may influence the pricing behavior of IPOs by the underwriting firm. Empirical studies have demonstrated that underwriters (investment bankers) are risk averse. Without the ability to hedge the risk of holding the issuing firm's stock, it is difficult to shift the risk to another party through derivatives. Therefore, there is strong incentive for the underwriter to under price the IPO.

When a firm goes public its ownership becomes widely dispersed, as firms raise new equity capital and as the original owners seek to diversify their stock holdings. A firm going public might also be willing to under-price its shares in order to generate excess demand for the offering. With excess demand, the firm could spread the shares among many different investors, with no single investor holding a significant block of stock. This widely dispersed ownership structure may benefit the firm by providing the company with a more liquid market for their shares. Firms might also be encouraged to under price their shares by the underwriter if the investment bank holds longterm warrants to buy more shares from the firm (over-subscription provision) if excess demand is present.

Another explanation is to assume that firms under-price their IPOs to achieve higher stock valuations when they expect to conduct future seasoned secondary offerings. For example, a firm with excellent prospects for growth might be willing to leave "money on the table" in the initial offering. If investors recognize and respond to this signal, then the long-term value of the firm's shares will be higher, and it can recoup the initial under-pricing costs in future equity offerings.

From the behavioral finance perspective, the following explanations for this irrational behavior are plausible. First, given the problem of the winner's curse, firms (in conjunction with their underwriters) may have to under-price shares, on average, to keep the market for IPOs functioning by providing liquidity to investors and owners. This market is vital to entrepreneurs who wish to harvest the value in their startup firms. Generally, relatively unsophisticated investors receive larger allocations of the IPOs with negative returns and smaller allocations of those with positive returns. Unless these investors receive winners at an acceptable frequency, they would eventually cease participating in the market.

Another theory is that the information advantage of investment banks over IPO issuers can be utilized to under-price the issue. Arguably the underwriter knows the market and what it will bear. An oversubscribed offering increases their attractiveness to the issuing firm. As a result, underwriters have an incentive to under-price the IPO to ensure that investors will fully subscribe to the offering and maybe even want more. On the down side, if an offering is not oversubscribed, the reputation of the underwriting syndicate may be damaged.

Empirical studies have demonstrated that the first day's abnormal return is usually short-lived and that an IPO is not always underpriced in the long term (Loughran and Ritter, 1995). In fact, IPOs may be generally overpriced based upon the longer term performance of risk equivalent securities. Drs. Loughran and Ritter's seminal 2005 study matched each IPO firm with an IPO non-issuing company of similar market cap size closest to, but higher than, that of the issuing firm. Each of the paired stocks was then followed for at least five years from the first trading day of the IPO. The results of this study indicated IPOs generally perform as well as the matched proxies for at least the first six months. In the six months following the offering, IPO firms in the study actually lost $1.1 \%$, versus a $3.4 \%$ gain for the comparable matching firms. IPOs generally continued to underperform over the next three years, with the gap narrowing but persisting well into the seventh year following the IPO. During the 20-year period the researchers studied, the average annual return over the five-year period following the IPO was $5.1 \%$ for the new issues and $11.8 \%$ for the comparable firms. These findings suggest that the "new issues puzzle" can be looked at as a new issue valuation problem due to the lack of available financial information. This under pricing provides a reason for the failure of capital markets to reduce the amount of "money left on the table". The critical question is whether this failure is the result of limited arbitrage opportunities available (an inefficient market) or a market anomaly.

The EMH suggests that the price of an IPO is correct; however, both stock anticipation and investment sentiment contributes to first day stock jumps. Over-reaction bias on anticipation of the new offering and the hype usually surrounding the IPO causes investors to over react. Ljungqvist and Wilhelm (2002) state that there is a range of behavioral biases that exist in equity markets in general and IPO pricing in particular. Their explanation for 
the IPO stock under-pricing phenomena is given by behavioral biases such as investor overconfidence. Welch and Ritter (2002) state that excessive optimism of investors might be an explanation of the price leaps when trading opens. The same behavioral biases that affect the IPO pricing phenomenon can also explain the subsequent low returns during the first few years of trading.

Several studies indicate that IPO issuing companies tend to take advantage of the market's inefficiency when raising capital. Because these findings challenge the notions that investors are rational and financial markets are efficient, they are controversial. More recent research casts doubt on this long-run underperformance for IPO shares. Studies by Brax and Gompers, Fama, Brav, Greczy and Gompers, Echkbo, and Masulis conclude that most IPOs do not yield significant long-run underperformance, provided that IPO returns are compared to an appropriate benchmark. In particular, Eckbo, Masulis and Norli make a compelling case that much of the observed underperformance can be explained by debt/equity reduction. resulting from the IPO recapitalization. They show that a company's raising of new equity capital in an IPO reduces the firm's leverage and ergo it's financial risk. As a result, investors are willing to accept a lower return subsequent to the offering. They also demonstrate that underperformance disappears when calendar time returns are used to compute abnormal performance rather than event-time returns, which weight active IPO issuance months more heavily than less active months.

Cornelli, Goldreich and Ljungqvist (2004) stated that the existence of behavioral biases can explain low return on an IPO during the first few years of trading. When small investors are pessimistic and value shares below fundamental values, the stock will be underpriced. When small investors bid up the price of the stock in the short run, there is often a reversal as the price converges towards the fundamental value in the long run. Miller (1977) stated that IPO market prices are determined at the margin by "optimistic investors". As more information becomes available about a firm, investors beliefs will converge and the marginal holder will no longer be as over-optimistic (Ritter (1991), Loughran and Ritter (1995)). The authors assume the existence of IPO underperformance notwithstanding recent papers that have questioned its nature and significance Brav, Geczy, and Gompers (2000), Eckbo and Norli (2001)).

Ljungqvist and Jenkinson (1996) offered the behavioral explanations of under-pricing reasons such as: the winner's curse; under-pricing as a signal; issuer or underwriter liability; and under-pricing as a marketing event. In the winner's curse situation, less informed investors receive shares of an IPO. If under-pricing did not exist then uninformed investors would be continually stuck with the "lemon" problem. However, with under-pricing, uninformed investors will have a chance to earn positive returns. According to the signaling explanation of underpricing that is how high- value firms indicate or signal to investors that the stock value is high. It is also less costly for high value firms to under-price their shares vis-à-vis low-value firms.

Among the market timing theories, McDonald and Lucas (1990) developed an asymmetric information model. In this theory, entrepreneurs will postpone going public if they perceive that the market value of their firm is too low. Ritter, Rydqvist, and Loughran (1994) were the earliest to study differential patterns of IPO commencing worldwide, presenting that IPO under-pricing virtually exists in all the countries. Faugeron-Crouzet and Biasis (2002) determined that a uniform price Dutch auction can actually stop unspoken agreements between bidders while extracting pre-existing information from investors similar to the book-building procedure used in most IPOs in the U.S.

One behavioral explanation of issuer or underwriter liability is that investment bankers are concerned with potential lawsuits if an IPO breaks below the issue price. Underwriters would depress the offering price to limit liability. Many underwriters frequently take warrants as part of their compensation; under pricing makes gives these warrants immediate value. Usually underwriters are obligated to prevent a price drop in the aftermarket. This is known as the price-support explanation of under pricing. Therefore, it is apparent that under pricing is not an enigma but rather an explainable behavior phenomenon.

Another behavioral explanation of under-pricing is that it is a marketing event. Buyers and owners of firms going public during 1998-2000 may have wanted to associate an IPO's success with very high first day return. Marketing "pop" was created when firms saw big price increases in their underpriced shares. Maksimovic and 
Pichler (2001) confirmed that a large price increase can encourage greater market participation. Other behavioral explanations of under pricing are the 'winner's curse' [Rock (1986)], signaling [Allen and Faulhaber (1989), Welch (1989)], cascades [Welch (1992)], and investor incentives to reveal information truthfully [Benveniste and Spindt (1989)]

The virtual impossibility of pricing IPOs precisely in tandem with the lack of capability to hedge causes underwriters to assume unquantifiable risks. It is very difficult to determine the appropriate price for an IPO. There is no recordable market price before issuing the stock. Most of the time, issuing companies do not have much operating history. The issuing firm will not get full advantage of the raised capital if an IPO is priced too low. However, there is a significant risk to the investment banks is an IPO is priced too high. An additional risk to the investment bank is that investors who bought the overpriced IPOs will shun future offers.

There are many behavioral implications to setting the price range and the number of shares to be sold in the offering. The ultimate stock price, relative to the stated range, is hypothesized to influence the IPO's short term performance. Consistent with the model of Benveniste and Spindt (1989), several studies report a correlation between the difference between the final offer price and the midpoint of the stated price range and the first-day return. This would suggest that IPOs priced above the price range are more likely to be heavily under-priced. Conversely, those shares offered below the price range will be less underpriced. Loughran and Ritter (2002) and Lowry and Schwert (2004) both report that those IPOs where the final offer price is revised upwards display a higher first-day return than those where the final offer price is revised downwards. If the private information of investors was entirely incorporated into the final offer price, then no relation between the price revision and underpricing should have been evident.

Lowry and Schwert (2004) demonstrate that public information is fully incorporated into the offer price, but typically private information tends to be only partially incorporated into it. They also show that negative information learned during the pre-marketing phase is more fully incorporated into the offering price than positive information. Both the underwriters and firms do not want to incur losses on overpriced issues because of potential litigation. Pricing IPOs is difficult task. The market is not certain about the quality of the IPO, while the issuing firm and its underwriter(s) do not know what the clearing price will be. The problem facing an underwriter wanting to collect information useful to pricing an IPO is that investors have no reason to truthfully reveal their private information during the pre-marketing phase. IPO investors receive "informational rents" for providing underwriters with the information necessary for the setting of the final IPO price.

Beneniste and Spindt (1989) found that for institutional investors to reveal their true interest in the shares, they demand more under-pricing. At the beginning of the book-building process, the underwriter proposes a price range for the shares. The book-building is based upon the investors placing indications of interest (IOI) for shares predicated upon the price range. When investors make their indications known, they clearly factor in their expectations about the initial market price. From these IOIs, the underwriter learns positive and negative information to be used to set the final offer price. To reward investors, the final offer price usually only partially incorporates the collected private information. As a result, these investors appear to earn a higher first-day return than those who buy in the secondary market. The book-building approach, which was adopted by U.S. investment bankers in the 1990s, is a more efficient method of pricing IPOs than that used in the past. This approach has reduced information asymmetry and thus the under-pricing in the U.S. over time. 


\section{ANALYSIS}

Table 2A: Descriptive Statistics for 2006 IPOs

\begin{tabular}{|c|c|c|}
\hline Variable & Mean & Median \\
\hline IPO Price Relative to Range & 1.975 & 2.000 \\
\hline Money Left on Table & $\$ 24,965$ & $\$ 5,440$ \\
\hline Number of Shares Issued & 12,751 & $\$ 1,850$ \\
\hline IPO Price & $\$ 15.52$ & $\$ 123.53$ \\
\hline Deal Size & $\$ 219.11$ & $28 \%$ \\
\hline Dilution of Ownership & $32 \%$ & $\$ 16.08$ \\
\hline Opening Price & $\$ 16.50$ & $0.72 \%$ \\
\hline Percent Change & $0.67 \%$ & $5.56 \%$ \\
\hline First Day Percent Change in Price & $11.6 \%$ & $7.20 \%$ \\
\hline Totermarket Return & $13.30 \%$ & $17.20 \%$ \\
\hline
\end{tabular}

Descriptive statistics for 1st day percent change in price are found in Table 2, and the corresponding histogram for this variable is found in Figure 1.

Table 2B: Descriptive Statistics for 1st Day Percent Change in Price

\begin{tabular}{|c|c|}
\hline Sample Size & 193 \\
\hline Mean & 11.55 \\
\hline Standard Deviation & 19.03 \\
\hline Minimum & -29.55 \\
\hline First Quartile & 0.00 \\
\hline Median & 5.56 \\
\hline Third Quartile & 16.96 \\
\hline Maximum & 125.41 \\
\hline Mode & 0.00 \\
\hline Coefficient of Skewness & 2.41 \\
\hline
\end{tabular}

Figure 1: Histogram for 1st Day Percent Change in Price

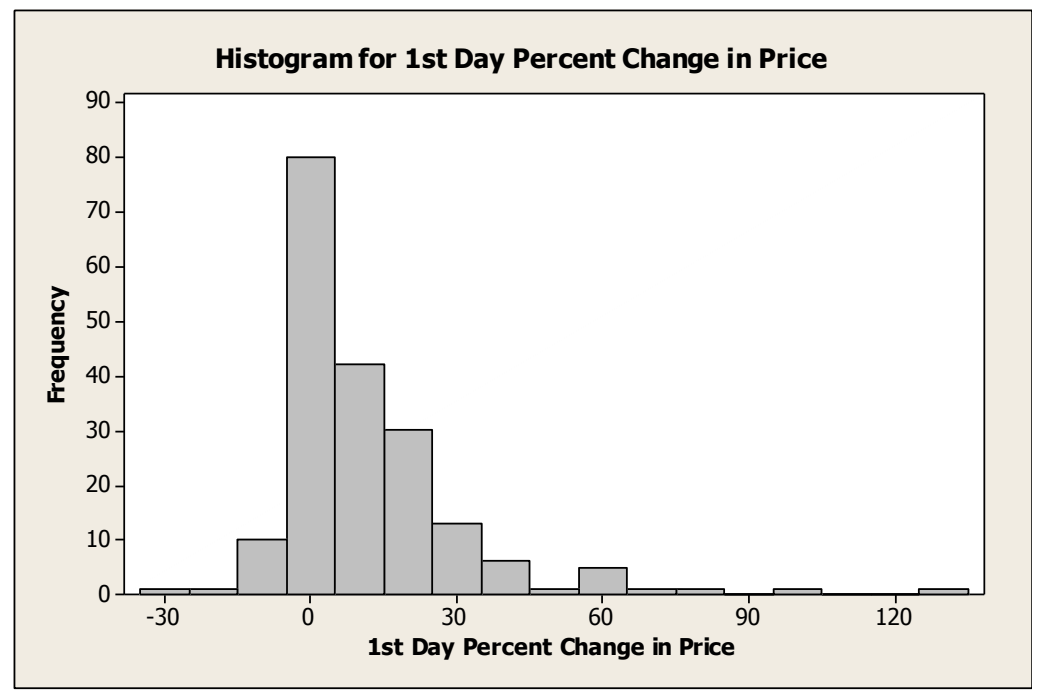


The sample data shows a variable with a distribution that has a single peak and a right or positive skew. The existence of a right skew can be confirmed by noting that the mean (11.55) is larger than the median (5.56), which in turn is larger than the mode (0.00). Furthermore, the positive sign on the coefficient of skewness also indicates that this variable is skewed right. A one-sample t-test was conducted to determine if the mean for this variable is significantly different than the median. The results of this test are found in table 3 .

Table 3: Results of One-Sample t-Test of the Mean $(\alpha=0.05)$

\begin{tabular}{|c|c|c|c|c|c|c|c|}
\hline Mean & Median & Difference & Std. Error & df & Computed t & Critical t & p-value \\
\hline 11.55 & 5.56 & 5.99 & 1.37 & 192 & 4.37 & 1.9724 & 0.000 \\
\hline
\end{tabular}

Of direct interest to the EMH, results obtained in this study and that of Miller and Reilly (1987) and Ibbotson, Sindelar, and Ritter (1994) indicate that the price adjustment to the under-pricing takes place within one day after the offering. The rapid adjustment of the initial under-pricing appears to support the semi-strong form of the EMH. For 2006, the mean first day return was $11.6 \%$. However, if the investor buys shares in the secondary market and holds them for the long-term, the returns are much less rewarding, albeit they are still lucrative. The average after market returns on all IPOs during 2006 was $27 \%$ compared to one day gains $11.6 \%$.

In this paper, we developed a behavioral model that explains this seemingly inefficient pricing behavior. Large IPOs tend to be less underpriced than smaller offerings. The smaller the size of the offering, the more it is underpriced. Moreover, initial returns are much greater during bull markets than in more normal times. It has been well documented that investors in financial markets are prone to irrational exuberance and this behavior is clearly consistent with that the tenets of behavioral finance.

The mean initial return is much higher than the median. The "headline" under-pricing figures are significant, with 60 to 70 percent of all IPOs being substantially underpriced. The median IPO's initial return is roughly half the value of the mean, with the average being inflated by a relative handful of popular offerings with initial returns of $50 \%$ or more. The mean first day return was $11 \%$, compared to the median first day return of $5.5 \%$. The mean return overstates the actual profits earned by most investors. According to Rock (1986), unsophisticated investors face the classic behavioral problem of the "winner's curse." When an IPO is extremely "hot", both sophisticated and unsophisticated investors will demand shares, and the issue will be heavily oversubscribed. In these oversubscribed deals, unsophisticated investors will be rationed, receiving only a fraction of the shares they requested. However when the deal or book making is weak, these unsophisticated investors receive much greater allocations of the IPOs.

Given a desired market capitalization value, firms going public must determine the number of shares and the price. While this marketing decision would seem to have little economic significance, the empirical evidence from stock splits suggests that firms do not choose their IPO share price level arbitrarily. The results of our study suggest that economically significant differences exist across firms choosing different IPO prices in the amounts of "money left on the table."

\section{REFERENCES}

1. Affleck, Graves. Heade, John, Shantaram, M., Conditional price trends in the aftermarket for initial public offerings. Financial Management. Winter 1996.

2. Aggarwal, R.and Rivoli,P.(1990) Fads in the Initial Public Offering Market? Financial Management, 19(4):4557.

3. Allen, F. and Faulhaver, G. (1989). Signaling by Under-pricing in the IPO market Journal of Financial Economics, 23(2) pp.303-323.

4. Benveniste, L. M. and Spindt, P. (1989). Information externalities and the role of underwriters in primary equity markets, Journal of Financial Intermediation1 1(1):61-86.

5. Bossaerts, P. (2004) Filtering Returns for Unspecified Biases in Priors When Testing Asset Pricing Theory. Review of Economic Studies. 71(1):pp. 63-86.

6. Bossaerts, P and Hillion, P. (2001). IPO Post-Issue Markets: Questionable Predilections but Diligent Learners? Review of Economics and Statistics, 83(2)pp. :333-347. 
7. Bradley, D., Jordon, B., Roten, I., and Yi, H. Venture Capital and IPO Lockup Expiration, Journal of Financial Research, 24 (4); pp. 465-493.

8. Bray, A.,Geczy, C., and Gompers, P. (2000) Is the abnormal return following equity issuances anomalous? Journal of Financial Economics, 56(2):pp. 209-249

9. Chung, Kee., Limn Yu, Linda. Assets in place, growth opportunities, and IPO returns. Financial Management, Autumn 2005.

10. Cornelli, Francesca, David Godreich, and Alexander Ljungqvist. Investor Sentiment and Pre-Issue Markets. London Business School and CERP; New York University and CERP (2004): pp. 1-65.

11. Cornelli, Francesca, David Godreich (2003). Book-building: How informative is the order book? Journal of Finance, 58(4):pp. 1415-1443.

12. Daily, Catherine. Certo, M. Dal, Travis. IPO under-pricing: a meta-analysis and research synthesis Entrepreneurship: Theory and Practice, Spring 2003.

13. Derrien, F. and Womack, K SEC Sues CSFB for IPO Violations: CSFB Will Pay \$100 Million. Securities and Exchange Commission. 3 June 2007 < http://www.sec.gov/litigation/litreleases/lr17327. Auction vs. book building and the control of under-pricing in Hot IPO markets, Review of Financial Studies, 69, pp. 117- 146

14. Fama, E. and French, K. (1992). The cross-section of expected stock returns, Journal of Finance, 47(2):427-465.

15. Fama, E. F. (1998). Market efficiency, Long-run returns and behavioral finance, Journal of Financial Economics, 49(3):283-306.

16. Hanley, K. (1993). The Under-pricing of IPOs and the partial adjustment phenomenon. Journal of Financial Economics, 34(2):pp. 231-250.

17. Jain, Bharat A.. The under-pricing of 'unit' initial public offerings., Quarterly Review of Economics and Finance, Fall 1994 Issue

18. Jegadeesh, N., Weinstein, M. and Welch, I., (1993) An Empirical Investigation of IPO Returns and subsequent equity offerings. Journal of Financial Economics, 34(2):pp. 153-175.

19. Keloharju, M. 91993). The winner's curse, legal liability, and the long-run price performance of IPOs in Finland. Journal of Financial Economics, 34(2):pp. 251-277.

20. Leite, T. (2004) Excess Initial Returns in IPOs. Journal of Financial Intermediation, 13(3):359-377.

21. Ljungqvist, A. (1997) Pricing Initial Public Offerings: Further evidence from Germany. European Economic Review, 41(7):pp.1309-1320.

22. Ljungqvist, Alexander, and William Willhelm, Jr. Does Prospect Theory Explain IPO Market Behavior. New York University Stern School of Business; University of Virginia McIntire School of Commerce (1999):pp. 172.

23. Ljungqvist, A. and Wilhelm, W., (2003) Hot markets, investor sentiment and IPO pricing Journal of Finance, 58 (2):pp. 723-752.

24. Ljungqvist, A., T.J. Jenkinson, and W.J. Wilhelm, (2003), Global integration in primary equity markets: The role of U.S. banks and U.S. investors, Review of Financial studies, 16, 63-69

25. Loughran, Tim, and Jay Ritter. Why Has IPO Under-pricing Changed Over Time? University of Notre Dame; University of Florida (2001).

26. Loughran, Tim, and Jay Ritter. (1995) The new issue puzzle Journal of Finance, 50(1):23-51

27. Mcnamee, Mike. Commentary: IPOs: Getting the Price Right. Business Week. 3 June 2002

28. Prentice, Robert. Whither securities regulation? Some behavioral observations regarding proposals for its future. Duke Law Journal, March 2002.

29. Ritter, Jay R. Differences Between European and American IPO Markets. European Financial Management 9 (2004): 421-434.

30. Ritter, J.R., 1984, The 'Hot Issue' Market of 1980, Journal of Business, 57, pp. 215-240

31. Ritter, J.R, and I. Welch, 2002, A Review of IPO Activity, Pricing, and Allocations, Journal of Finance 57, pp. 795-828

32. Ritter, J.(1991) The long run performance of Initial Public Offerings Journal of Finance, 46(1):3-27.

33. Ritter, Jay, Kristian Rydqvist, and Tim Loughran. Initial Public Offerings: International Insights. Pacific-Basin Finance Journal (1997):pp. 1-7.

34. Rock, K. (1986). Why New Issues are Underpriced. Journal of Financial Economics, 15(1-2);187-212.

35. Thornton, Emily. Commentary: How to Clean Up Wall Street's IPO Machine. Business Week (2003). <http://www.businessweek.com/print/magazine/content/02_36/b3798118.htm

36. Top Performing IPOs (Last 12 Months). IPO Home. 3 June 2007 <http://www.ipohome.com/marketwatch/performance.asp?sort=offer\&order=DE SC $>$. 